\title{
Minimally invasive sacrospinous ligament suspension: perioperative morbidity and review of the literature
}

\author{
Melike Doğanay • Orhan Aksakal
}

Published online: 17 August 2013

(c) Springer-Verlag Berlin Heidelberg 2013

Sir,

First of all, thank you for your interest in our study (Minimally invasive sacrospinous ligament suspension: perioperative morbidity and review of the literature) [1].

The duration of SSLS in our study is defined as the time period between incision of posterior vaginal wall and suturing of vaginal apex. Closing of vaginal wall was not included in the duration of SSLS.

More bleeding was seen in the group of Deschamps suture carrier because of wider dissection. So control of bleeding took more time than normal.

We hope to send the video file of operation with the automatic suturing instrument, designed by Aksakal [2], as soon as possible.
Conflict of interest None.

\section{References}

1. Doğanay M, Aksakal O (2013) Minimally invasive sacrospinous ligament suspension: perioperative morbidity and review of the literature. Arch Gynecol Obstet 287(6):1167-1172. doi:10.1007/ s00404-012-2687-6 (Epub 2012 Dec 29)

2. Aksakal OS, Ozyer SS, Güngör T, Doganay M, Bilge U, Mollamahmutoğlu L (2007) 'Comparison of a new technique with deschamps ligature carrier for sacrospinous ligament fixation'. Arch Gynecol Obstet 276(6):591-594
M. Doğanay · O. Aksakal

Department of Obstetrics and Gynecology, Zekai Tahir Burak

Mother Health Training and Research Hospital, Ankara, Turkey

M. Doğanay $(\bowtie)$

Cukurambar Mah. 1429. Cad., Ozalp Apt. No: 7/39,

Yuzuncuyll-Ankara, Turkey

e-mail: drmdoganay@gmail.com 